Communities and Caring 


\author{
Also by Marjorie Mayo \\ Community Action for Change (with Ray Lees) \\ Community or Class Struggle? \\ (editor with John Cowley, Adah Kaye and Mike Thompson) \\ Community Work One (editor with David Jones) \\ Community Work Two (editor with David Jones) \\ Women in the Community (editor)
}




\title{
Communities and Caring
}

\author{
The Mixed Economy of Welfare
}

Marjorie Mayo

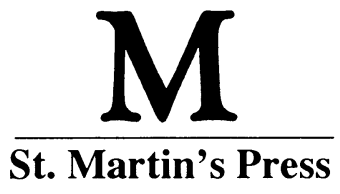


All rights reserved. No reproduction, copy or transmission of this publication may be made without written permission.

No paragraph of this publication may be reproduced, copied or transmitted save with written permission or in accordance with the provisions of the Copyright, Designs and Patents Act 1988, or under the terms of any licence permitting limited copying issued by the Copyright Licensing Agency, 90 Tottenham Court Road, London W1P 9HE.

Any person who does any unauthorised act in relation to this publication may be liable to criminal prosecution and civil claims for damages.

First published in Great Britain 1994 by

THE MACMILLAN PRESS LTD

Houndmills, Basingstoke, Hampshire RG21 2XS

and London

Companies and representatives

throughout the world

A catalogue record for this book is available

from the British Library.

First published in the United States of America 1994 by

Scholarly and Reference Division,

ST. MARTIN'S PRESS, INC.,

175 Fifth Avenue,

New York, N.Y. 10010

ISBN 978-0-333-56751-7

Library of Congress Cataloging-in-Publication Data

Mayo, Marjorie.

Communities and caring : the mixed economy of welfare / Marjorie

Mayo.

p. $\mathrm{cm}$.

Includes bibliographical references and index.

ISBN 978-0-333-56751-7

1. Community development-Great Britain. 2. Public welfare-Great

Britain. 3. Great Britain-Social policy. I. Title.

HN400.C6M39 1994

307 . 1' 4' $0941-\mathrm{dc} 20$ 
To Clyde and Scarlet 


\section{Contents}

Acknowledgements viii

Introduction: The Changing Parameters of Debate 1

1. The Mixed Economy of Welfare: Unravelling Some Myths and Identifying some Choices

2. The Shifting Concept of Community

3. Policies for Jobs and Training: Community

Development and Local Economic Development

4. Some International Comparisons from the North 90

5. Some International Comparisons from the South

6. The Changing Role and Potential of the Non-Statutory Community Sector in Britain

7. Community Participation in Planning and Community Service Provision

$\begin{array}{ll}\text { 8. Conclusion } & 195\end{array}$

$\begin{array}{ll}\text { References } & 209\end{array}$

$\begin{array}{ll}\text { Index } & 228\end{array}$ 


\section{Acknowledgements}

I owe very particular thanks to the community organisations who shared their experiences, and especially so to the Afro-Caribbean Organisation, Alexandra and Ainsworth, Kilburn Vale and Highgate Newtown Tenants Organisations, Camden Federation of Tenants and Residents, Ferguslie League of Action Groups, and the Pinehurst People's Centre.

Many thanks, too, to colleagues at Ruskin College, Oxford, and the William Temple Foundation, Manchester, who worked together on the Communities in Crisis programmes of community education, experiences which raised a number of the questions that appear in this book.

I should also like to thank a number of individuals who commented upon drafts of specific chapters and made extremely constructive criticisms and suggestions, including Bill Bryant, Richard Bryant, Pauline Conroy, David Marsden and Ines Newman. Any remaining errors are, of course, mine.

My thanks, too, to Jo Campling, who as editor has been consistently supportive and constructive, as well as personally encouraging, and to Frances Arnold and Keith Povey.

And last but by no means least, my thanks to Laurence, Clyde and Scarlet Harris, whose support has included the most patient assistance and encouragement in combating my technophobia with the word processor, and to Sue Coles, who then took on the task of turning the draft into a more professionally presented typescript.

MARJORIE MAYO 